\title{
Registration of Transfers of Land of Rights for Nominee in the Post of Tax Amnesty
}

\author{
$1^{\text {st }}$ Mahendra Wardhana, S.H, M.Kn \\ Law Department, Faculty of Social Sciences \\ and Law \\ Universitas Negeri Surabaya \\ Surabaya, Indonesia \\ mahendrawardhana@unesa.ac.id
}

\author{
$2^{\text {nd }}$ Indri Fogar Susilowati \\ Law Department, Faculty of Social Sciences \\ and Law \\ Universitas Negeri Surabaya \\ Surabaya, Indonesia \\ indrifogar@unesa.ac.id
}

\author{
$3^{\text {rd }}$ Dita Perwitasari \\ Law Department, Faculty of Social Sciences \\ and Law \\ Universitas Negeri Surabaya \\ Surabaya, Indonesia \\ dita.perwitasari@gmail.com
}

\begin{abstract}
National development relies heavily on the participation and financing from the people through receipt of tax payments. But not all economic activities carried out by the public are reported to the authorized tax authorities. The unreporting of all these economic activities resulted in a reduction in the potential for tax revenue for the country. For this reason, the state needs to make a breakthrough to increase the country's revenue. The special step taken by the government is to enact Law Number 11 of 2016 concerning Tax Amnesty. Tax Amnesty is the abolition of taxes that should be owed, not subject to tax administration sanctions and criminal sanctions in the field of taxation, by disclosing the Property and paying the Ransom. One potential tax revenue that has not been fully explored is income tax $(\mathrm{PPh})$ on the transfer of land rights and land rights acquisition (BPHTB). The people who buy and sell land do not immediately actively report their economic activities to the tax authorities, where proof of ownership is still written on behalf of the old seller. In accordance with the Regulation of the Minister of Agrarian and Spatial Planning / Head of the Republic of Indonesia National Land Agency Number 15 of 2017 concerning Registration of Transfers of Land Rights in the Context of Tax Amnesty, that land and buildings relating to land owned by Taxpayers are still registered in the name of another person or Nominee, must be transferred to on behalf of the Taxpayer.
\end{abstract} Rights

Keywords-Tax Amnesty, Nominee, Transfer of Land

\section{INTRODUCTION}

National development that aims to create a just and prosperous society requires huge capital. Capital, both in the form of money and in other forms that have economic value, has an important role, at least 2 (two) things, namely: first as an investment in an effort to increase economic growth to create prosperity for the people; second, economic growth will increase tax revenues.[1]

Serious budgetary shortfalls have plagued state and local governments for a number of years. Traditionally, budgetary shortfalls arose from government failures such as excessive spending, optimistic projections, and modest tax collections.[2]

The potential for tax revenue should increase along with economic growth. One of them is the application of tax derived from Income Tax (PPh). Income Tax is a central tax that has been regulated in Law Number 7 of 1983 concerning Income Tax as amended several times by Law Number 36 of 2008.

$\mathrm{PPh}$ is collected based on the Self Assessment System, so the taxpayer calculates how much tax must be paid annually. Since the beginning of the implementation of this system on January 1, 1984 was used as the beginning of the implementation of "clean" taxation based on the honesty of taxpayers to report income received and assets purchased, especially assets in the form of immovable property in this case land and or buildings.

But of course, not all economic activities carried out by the taxpayer are reported to the state. And of course, this is the thing that has resulted in reduced state revenue. Even though the tax is indeed a pengutan whose nature can be imposed on the taxpayer. The absence of direct achievement of taxpayers in paying taxes makes people reluctant to pay taxes. This is also caused by people who pay taxes and people who do not pay taxes can use the same facilities from the country as the use of highways, or other facilities.

Viewed from the point of view of the taxpayer, this situation certainly creates jealousy, injustice among fellow taxpayers, because one taxpayer pays higher taxes than another taxpayer whose income or wealth is relatively the same. Also happens someone pays taxes while other people who have the same income do not even pay taxes. [1]

The focus is on tax enforcement. This has a major implication. Unlike other law enforcement, tax enforcement normally based on self reporting, which in fact provides $e x$ ante the screening and insurance servicescredited to settlements. The addition of a settlement stage to an enforcement system based on self-reporting implies, de facto, a double screening of taxpayers, once when they report their liability, and again whenthey decide whether or not to pay the settlement amount. As such, the penalty negotiation involved in the settlement stage represents a form of consensual "renegotiation" of statutory enforcement rules, aimed at overcoming ex post inefficiencies attendant on the original enforcement procedure (which, to be sure, is not "negotiated" but rather imposed on individuals). As is amply shown in the optimal contract literature, the possibility of renegotiating the original plan cannot increase the ex ante (expected) payoff to the principal, unless it occurs after some new non-verifiable information has 
become available to the parties. (To see this, it is sufficient to apply the revelation principle).[3]

For this reason, the state needs to make a breakthrough to increase the country's revenue. The special steps taken by the government are by enacting Law Number 11 of 2016 concerning Tax Amnesty (hereinafter referred to as the Tax Amnesty Act). Tax Amnesty is the abolition of taxes that should be owed, not subject to tax administration sanctions and criminal sanctions in the field of taxation, by disclosing the Property and paying the Ransom. The Tax Amnesty Policy is carried out in the form of the release of the state's right to collect taxes that ought to be owed.

Etymologically, the term tax amnesty comes from the word "tax amnesty", a concept that has been applied in several countries such as United States of America, Germany, Canada, Sweden, Netherlands, Norway, Belgium, France, Switzerland, Finland, Portugal, Russia, Rep of Ireland, Italy, Malaysia, Pakistan, Sri Lanka, India, Philippines, New Zealand, Australia, Chile, Colombia, Costa Rica, Ecuador, Indonesia, Bolivia, Venezuela, Puerto Rico, Honduras, Mexico, Panama, Brazil, Argentina.[4]

In various countries that have implemented tax amnesty are part of the country's fiscal policy program, which aims to increase state revenues in the short term. The same view of this goal was stated by Eric Le Borgne. According to Eric Le Borgne, in addition to increasing state revenue in the short term, tax amnesty also aims to increase taxpayer compliance so that it can increase horizontal justice and increase income in the medium term.[4]

The word amnesty comes from the Greek "amnestia" which can mean forgetting or an act of forgetting. Experts interpret amnesty into different meanings, in accordance with the field of legal application, including as a concept of elimination or elimination of criminal responsibility, for example “.....a general overlooking or pardon of past offenses by the ruling authorithy' atau sebuah tindakan dimana "which crimes against the government up to a certain date are so obliterated that they can never be brought into charge.[5] Other views not only limit the concept to the elimination of criminal responsibility, but also include the elimination of civil liability. In the black law dictionary, it says " (a) sovereign act of oblivion for past act, granted by a government to all persons (or certain persons) who have been guilty of crime or delict, generally political offenses, and often conditional upon their return to obedience and duty within prescribed time.[6]

Although tax amnesty is not the only solution to overcome budget difficulties, however, if forgiveness is carefully designed and carried out consistently and followed by strict law enforcement then in the long-term tax amnesty will be beneficial in increasing investment. The positive side of the tax amnesty program is an increase in state revenues from the tax sector without incurring new burdens for the community, because tax amnesty basically takes the state's rights that have not been or are not paid for by paying taxpayers according to their obligations without any sanctions. In the tax it is known the principle that the state has the right to receive a certain amount of money, no more and no less, so the taxpayer is obliged to pay a certain amount, no more and no less, in accordance with the law. [1]

One potential tax revenue that has not been fully explored is income tax $(\mathrm{PPh})$ on the transfer of land rights and land rights acquisition (BPHTB). The people who buy and sell land do not immediately actively report their economic activities to the tax authorities, where proof of ownership is still written on behalf of the old seller.

Income Tax on the transfer of land and or building rights is regulated in Government Regulation Number 36 of 2016 concerning Income Tax on Income from Transfer of Land Rights and / or Building and Contract of Sale and Purchase Agreement on Land and or Building and its amendments (hereinafter referred to as PP concerning Transfer of Rights for Land and or Building). Whereas the Customs of Acquisition of Land and or Building Rights is regulated in Law Number 20 of 2000 concerning Amendment to Law Number 21 of 1997 concerning the Obligation to Obtain Land and Building Rights.

Pursuant to Article 1 paragraph (1) of the PP on the Income Tax on Transfer of Land and / or Building that on income received or obtained by a person or entity from:

a. transfer of land and / or building rights; or

b. the sale and purchase agreement of land and / or building and its amendments, final income tax payable.

In Article 1 paragraph (2) of the PP on the Income Tax on Land Transfer and / or Building it states that "Income from the transfer of land and / or building as referred to in paragraph (1) letter a is the income received or earned by the party who diverts the right land and / or building through sale, exchanges, rights relief, assignment, auction, grant, inheritance, or otherwise agreed between the parties.

Furthermore, it is mentioned in Article 1 paragraph (3) PP concerning PPh Transfer of Land Rights and or Income Building from the binding agreement on the sale and purchase of land and / or buildings along with the amendments as referred to in paragraph (1) letter $b$ is income from: a. the seller whose name is listed in the binding agreement when first signed; or $b$. the buyer whose name is listed in the contract of sale and purchase prior to the change or addendum to the agreement to buy and sell, for the change in the party of the buyer in the binding agreement.

The potential of state revenue through the $\mathrm{PPh}$ on Transfer of Land and or Building Rights and Land and Building Rights Acquisition Duty (BPHTB) is reduced when a taxpayer who buys land and or building does not return the name to the name of the buyer or recipient of the transfer so that the name written in proof of ownership (certificate) is still written on behalf of the old owner.

Under the Tax Amnesty Act, for the sake of legal certainty, increasing land services, as well as supporting the success of the tax amnesty program, it is necessary to regulate the registration of the transfer of land rights to the object of tax amnesty. For this reason the Government issued a Regulation of the Minister of Agrarian and Spatial Planning / Head of the Republic of Indonesia National Land Agency Number 15 of 2017 concerning Registration of Transfers of Land Rights in the Context of Tax Amnesty that are land and buildings relating to land owned by 
Taxpayers who are still registered in the name of another person or Nominees, must be transferred to the name of the Taxpayer.

Article 3 paragraph 1 of Regulation of the Minister of Agrarian and Spatial Planning / Head of the Republic of Indonesia National Land Agency Number 15 of 2017 concerning Registration of Transfers of Land Rights in the Context of Tax Amnesty confirms that this Regulation is only valid for the registration of the transfer of rights to land of Taxpayers registered in the name of a person another or Nominee in the context of implementing the Tax Amnesty Act.

Based on the problems that have been stated above, the following is the formulation of problems related to this writing (1) how the registration of land and buildings relating to land owned by taxpayers who are still registered in the name of another person (nominee), must be transferred to the name of the taxpayer?

\section{RESEARCH METHODS}

Legal research is a process of finding the rule of law, principles of law, and the legal doctrines in order to get solution of the legal issues. This is consistent with the prescriptive character of, legal research conducted to produce arguments, theories or new concepts as a prescription to solve problems. If descriptive study expected answers are true or false, the expected response in legal research is rigth, appropriate, inappropriate, or wrong. thus, it can be said that the results obtained in the study of law already contains values.

Based on definition above, normative research is trying to study and explore and find answers about what should be on every issue. In contrast to the descriptive study that only describes what is true, and what is false of any problems, and any factors that influence it.

The approaches used are statute approach and conseptual approach. Statute approach is examining all act and regulations relevant to the legal issues. Conseptual approach is examining notions and doctrines of the experts that developed in the jurisprudence. By studying notions and doctrines in the science of law, researcher would find the ideas that build notions of law, legal concepts, and principles of law that are relevant to the issues faced. An understanding of notions and doctrines is a foundation for researchers in building a legal argument in solving the issues faced.

\section{RESULTS AND DISCUSSION}

The national development of the Unitary State of the Republic of Indonesia which aims to prosper all the people of Indonesia that is equitable and equitable, requires large funding which is the main source of tax revenue. Even though taxes are always felt to be a burden for the community, especially the sales and purchase tax of a large house.

This is not always a bad thing. Property taxes are hugely important for state and local governments.[7] They can be an important source of revenue for governments experiencing financial difficulties or contemplating a significant one-time expenditure that promises great social benefit.[7]
The amount of tax that must be paid by a seller and buyer depends on the value of the property that is the object of sale and purchase. The government is currently trying to reduce interest rates, especially Home Ownership Loans, so property sales can increase and thus taxes paid by taxpayers will also increase following the value stated in the sale and purchase transaction.

The future path of house price is assumed to follow the same structure as the interest rate model.[8] This policy is expected to increase the purchasing power of people towards property as well as the potential for state revenue through the tax sector. While the plan would initially increase investment, rising interest rates would eventually decrease investment below baseline levels in later years. [9]

This effect would be attenuated to some degree because most tax reductions would accrue to high-income households, which are likely to increase spending proportionately less than would lowerincome households in response to increased after-tax income.[9]

The question remaining in this case, therefore, was whether the property was used to generate profit.[7]. Besides that, there are also many questions in cases like this. Because the potential of tax revenue can also be obtained from the potential for income tax on rental of property owned by a taxpayer. The percentage of $\mathrm{PPh}$ on rental properties is greater than buying and selling, which is $10 \%$ of the rental price. When even economic activities like this are not reported, tax revenues will also be reduced.

Not only does it not report the house buying and selling activities, so that the house that is the object of buying and selling still remains written on behalf of a seller, and does not report leasing activities. The potential of state revenue from the property purchase tax can also be reduced or not as big as the tax that should have been paid because of a price compromise between the seller and the buyer, so that the price written in the PPAT sale and purchase deed is not the same as the actual price.

Since the early twentieth century, federal tax law has determined the cash value of property using the concept of "fair market value," defined for certain federal income tax purposes as "the price at which the property would change hands between a willing buyer and a willing seller, neither being under any compulsion to buy or sell and both having reasonable knowledge of relevant facts[10].

This concept is indirectly also considered as a justification for taxpayers when they are obliged to sell and buy with other taxpayers, which causes tax revenue to be reduced.

These laws matter, because "fair market value" seems to require imagining, as part of the hypothetical arm's-length transaction, that the hypothetical buyer and seller complete the transaction without violating the legislated price floor or discrimination prohibitions.[10] Transactions are then considered legal by each taxpayer, although this reduces tax revenue.

This analysis is consistent with how "fair market value" is usually applied to property so as to account for statutes or regulations that restrict the use or sale of that property, such as zoning and environmental laws, or regulations on the sale of securities. [10] 
The problems as stated above are what then also spur the government to hold tax amnesty amid the pros and cons that occur in the community. Tax amnesty is held for the greater interest, namely the interests of the nation and the state.

The problems as stated above are what then also spur the government to hold tax amnesty amid the pros and cons that occur in the community. Tax amnesty is held for the greater interest, namely the interests of the nation and the state.

Whatever form the future nation-state takes, globalization offers nations and their tax systems both an abundance of benefits and some embedded perils.[11]. Tax amnesty is indeed two sides of a coin. On the one hand, the tax amnesty becomes a large potential state revenue through ransom paid by taxpayers, but on the other hand tax amnesty seems to be a program to legalize money laundering.

The emphasis on tax havens and harmful tax practices is not self-evident and has in fact drawn harsh criticism over the years.[11]. The basis of the argumentation in the Tax Amnesty Law is contrary to the constitution of the 1945 Constitution articles 23 and 23 A concerning the management of the State Expenditure Budget and tax collection, where the tax collection in the process of the State Budget Revenues is compelling, open forgiveness.

However, it must be understood that in the short term, this will be able to increase tax revenues in the year that the Ransom is received which is useful for the State to finance various planned programs. In the long term, the State will receive tax revenue from additional economic activities derived from Assets that have been transferred and invested in the territory of the Republic of Indonesia.

Such efforts, however, remain largely unrealized, resulting in significant revenue loss.[11] Several domestic factors, such as the size of public sector debt, act as counterweights to tax competition. In addition, attracting economic resources requires more than offering preferential tax treatment. [11] The government certainly has calculated all risks, as well as all potential revenues when running this tax amnesty.

In other words, all-or-nothing exemption is too rigid and heavy-handed a tool; a more nuanced, flexible system is needed.[7] For this reason, it is necessary to apply flexible special measures and policy breakthroughs to encourage the transfer of Assets into the territory of the Republic of Indonesia as well as provide security guarantees for Indonesian citizens who wish to transfer and disclose their Assets in the form of Tax Amnesty. This breakthrough policy in the form of Tax Amnesty on the transfer of Assets is also driven by the smaller possibility of hiding wealth outside the territory of the Republic of Indonesia because of the increasingly transparent global financial sector and the increasing intensity of information exchange between countries.

Exemption from property taxes costs many state and local governments a huge amount of revenue that could go to other important program.[7] With the funds obtained from the ransom from this tax amnesty, it can be used for important programs for the community for the benefit of all Indonesian people.

egulation of the Minister of Agrarian and Spatial Planning / Head of the Republic of Indonesia National Land
Agency Number 15 of 2017 concerning Registration of Transition of Land Rights in the Framework of Tax Amnesty provides legal certainty, enhances land services, and supports the success of tax amnesty programs, that land and buildings related to land Property of a Taxpayer who is still registered in the name of another person or Nominee, must be transferred to on behalf of the Taxpayer.

Pursuant to Article 1 of the Regulation of the Minister of Agrarian and Spatial Planning / Head of the Republic of Indonesia National Land Agency Number 15 of 2017 concerning Registration of Transition of Land Rights in the Framework of Tax Amnesty, that is in accordance with the provisions of Article 15 of Law Number 11 of 2016 concerning Tax Amnesty, then:

a. land and buildings relating to land owned by a Taxpayer who is still registered in the name of another person, or hereinafter referred to as a Nominee, must be transferred to on behalf of the Taxpayer;

b. transfer of rights as referred to in letter a is carried out through the signing of a Statement by both parties, namely Nominees and Taxpayers, before a Notary who states that the land and buildings referred to are owned by the Taxpayer;

c. transfer of rights as referred to in letter $a$ and letter $b$ is exempted from the imposition of Income Tax $(\mathrm{PPh})$ for Nominees;

d. in accordance with Law Number 28 of 2009 concerning Regional Taxes and Regional Levies, the Taxpayer is subject to the obligation to pay Land and Building Rights (BPHTB), which is calculated based on the NJOP of the current year on the land and buildings, in accordance with the provisions of the law invitation.

Furthermore, in Article 2 of the Regulation of the Minister of Agrarian and Spatial Planning / Head of the Republic of Indonesia National Land Agency Number 15 of 2017 concerning Registration of Transition of Land Rights in the Framework of Tax Amnesty, states that:

1) Taxpayers must register the transfer of rights referred to in Article 1 to the local Land Office in accordance with the provisions of the legislation.

2) Transfer of rights through a Statement and exemption from the obligation to pay $\mathrm{PPh}$ as referred to in Article 1 letter $\mathrm{b}$ and letter $\mathrm{c}$, and registration of transfer of rights as referred to in paragraph (1), only applies in the case of:

a. Taxpayers have obtained a Tax Amnesty Certificate and have paid the redemption in accordance with the provisions of the legislation; and

b. transfer of land rights and registration application for the transfer of rights to their land shall be carried out no later than December 31, 2017.

3) Certificate of Tax Amnesty and proof of payment of payment of redemption as referred to in paragraph (2) letter $\mathrm{a}$, as well as proof of payment of BPHTB payments as referred to in Article 1 letter d, attached to the application file for transfer of rights to their land, and can be in the form of derivative documents or a photocopy that has been approved in accordance with the original by the authorized official. 
4) The Head of the Land Office or the appointed official carries out the registration of the transfer of rights as referred to in paragraph (1) by recording in the Land Book and the Land Rights Certificate concerned, as follows: "Statement by both parties stating that the land and the building is properly owned by the Taxpayer made before a Notary: ............................. at ..................., on the day: ........................., date : ..., month: ….................., year: ….... Number: in accordance with the provisions of Article 15 of Law Number 11 of 2016 concerning Tax Amnesty in conjunction with Article 37 paragraph (2) of Government Regulation Number 24 of 1997 concerning Land Registration. "

It will explain that income tax is an application of the principle that tax liability should accord with ability-to-pay and that, in turn, ability-to-pay derives from a certain set of conceptions regarding distributive justice.[12] Taxpayers must understand the consequences when a taxpayer is able to carry out economic activities by buying a house so the taxpayer must be willing to pay according to the transaction

Some refer to sacrifice theory, according to which each person should experience the same degree of pain from paying taxes: because of the declining marginal utility of money, a wealthy individual would need to pay more than a poor person in order to experience the same degree of disutility.[12]

Residence is a matter of whose welfare is important. In designing the contours of its tax structure, a country's only or primary concern is promoting the welfare of its own residents.[12] Moreover, in this case a person who has more than one property does not show a contribution to the country by not paying taxes

Ability-to-pay, on the other hand, looks more to the person than to the service that the person receives. Instead of viewing taxpayers merely as a means of financing public expenditures and inquiring how the distribute the burden most fairly, it views them as people with needs and desires and it places at the forefront of the discourse not what the person received from the government but how the payment of tax will affect that person's welfare.[12]

Article 3 Regulation of the Minister of Agrarian and Spatial Planning / Head of the Republic of Indonesia National Land Agency Number 15 of 2017 concerning Registration of Transfers of Land Rights in the Framework of Tax Amnesty states that this Ministerial Regulation is only valid for the registration of the transfer of rights to the Taxpayer's land registered in the name of another person or Nominee in the framework of implementing Law Number 11 of 2016 concerning Tax Amnesty. (2) In the event that the registration of the transfer of land rights is done not in accordance with the provisions referred to in paragraph (1) the Taxpayer may be subject to sanctions in accordance with the provisions of the legislation

Unreported taxpayer's economic activity, which causes a taxpayer to have additional assets or property, so that the name must be immediately returned to the name of the buyer. This is in accordance with the mandate of the Regulation of the Minister of Agrarian and Spatial Planning / Head of the National Land Agency of the Republic of
Indonesia Number 15 of 2017 concerning Registration of Transfer of Land Rights in the Framework of Tax Amnesty

That rule would deny the donor of complex transfers the benefit of value freezing and any additional benefits available for lifetime transfers. That rule would also encourage outright transfers of property.[13] The transfer of land and building rights that are still written in the name of Nominee into the name of the Taxpayer becomes the main thing that must be done after the enactment of tax amnesty.

The Tax Amnesty Policy should be followed by other policies such as stricter law enforcement and improvement of the Law on General Provisions and Procedures for Taxation, Law on Income Tax, Law on Value Added Tax on Goods and Services and Sales Tax on Luxury Goods and other strategic policies in the field of taxation and banking.

\section{CONCLUSION}

Based on the discussion above it can be concluded that, taxpayers must register the transfer of rights to the local Land Office. Subsequently the transfer of rights through a Statement Letter and exemption from $\mathrm{PPh}$ payment obligations only applies in the event:

a. Taxpayers have obtained a Tax Amnesty Certificate and have paid the redemption in accordance with the provisions of the legislation; and

b. transfer of land rights and registration application for the transfer of rights to their land shall be carried out no later than December 31, 2017.

Tax Amnesty Certificate and proof of repayment of the payment of Redemption as well as proof of payment of BPHTB payment attached to the application file for the transfer of rights to the land, and can be in the form of derivative documents or photocopies that have been legalized in accordance with the original by the authorized official.

Head of Land Office or appointed official, registers the transfer of rights by recording in the Land Book and the relevant Land Rights Certificate

\section{ACKNOWLEDGEMENT}

Thank God I pray to Allah S.W.T and our beloved Prophet Muhammad, S.A.W because of his grace and mercy, finally I can finish this paper. With all the limitations that exist on the author, the preparation of the paper entitled "Pendaftaran Peralihan Hak Atas Tanah Nominee Paska Tax Amnesty" was the author try our best. The writing of this paper is to provide an overview and explanation of the legal aspects related to "Registration of Transfers of Land of Rights for Nominee in the Post of Tax Amnesty". The author realizes that this paper is far from perfect. That's why the authors gladly willing to accept suggestions and constructive criticism from readers.

\section{REFERENCES}

Z. Muttaqin, Tax Amnesty di Indonesia, 1st ed. Bandung: PT. Refika Aditama, 2012.

R. K. Johnson, WHO WINS RESIDENTIAL PROPERTY TAX APPEALS? 
[3] Luigi Alberto Franzoni, "Amnesties, Settlements and Optimal Tax Enforcement."

[4] J. Alm, "Tax Policies Analysis: The Introduction of a Russian Tax Amnesty," 1998

[5] Ifdhal Kasim, "Menghadapi Masa lalu: Mengapa Amnesti," Majalah Lembaga Studi dan Advokat Masyarakat (ELSAM), p. 2, 2000.

[6] Bryan A.Gerner, Black Law Dictionary. 1999.

[7] E. J. Santos, "PROPERTY TAX EXEMPTIONS FOR HOSPITALS: A BLUNT INSTRUMENT WHERE A SCALPEL IS,” 2016.

[8] T. Baer, I. Eroi, K. Pater, R. Pereira, and S. J. Yoo, "Pricing of Reverse Mortgage on Forward House Sale," Atlantis-Press.Com.

[9] J. Nunns, L. Burman, B. Page, J. Rohaly, and J. Rosenberg, “An Analysis of the House GOP Tax Plan," Tax Policy Cent., p. 37, 2016.

[10] C. Information, "Tax Liability for Wage Theft," vol. 1, 2012.

[11] S. Leviner, "The Intricacies of Tax \& Globalization," Ssrn, no. June 2012, 2013.

[12] T. H. E. Myth, O. F. Corporate, and T. A. X. Residence, "ARTICLES."

[13] W. C. Gerzog, "A Simpler Verifiable Gift Tax," Ssrn, 2014. 